\title{
T Cell Subpopulations in the Physiopathology of Fibromyalgia: Evidence and Perspectives
}

\author{
Giuseppe Banfi ${ }^{1,2}$, Marco Diani ${ }^{1}$, Paolo D. Pigatto ${ }^{1,3}$ and Eva Reali ${ }^{1, *}$ \\ 1 IRCCS Istituto Ortopedico Galeazzi, 20161Milan, Italy; banfi.giuseppe@hsr.it (G.B.); \\ marco.diani@unimi.it (M.D.); paolo.pigatto@unimi.it (P.D.P.) \\ 2 School of Medicine, Università Vita-Salute San Raffaele, 20132 Milan, Italy \\ 3 Department of Biomedical, Surgical and Dental Sciences, University of Milan, 20122 Milan, Italy \\ * Correspondence: eva.reali@grupposandonato.it
}

Received: 8 January 2020; Accepted: 10 February 2020; Published: 11 February 2020

check for updates

\begin{abstract}
Fibromyalgia is one of the most important "rheumatic" disorders, after osteoarthritis. The etiology of the disease is still not clear. At the moment, the most defined pathological mechanism is the alteration of central pain pathways, and emotional conditions can trigger or worsen symptoms. Increasing evidence supports the role of mast cells in maintaining pain conditions such as musculoskeletal pain and central sensitization. Importantly, mast cells can mediate microglia activation through the production of proinflammatory cytokines such as IL-1 $\beta$, IL- 6 , and TNF $\alpha$. In addition, levels of chemokines and proinflammatory cytokines are enhanced in serum and could contribute to inflammation at systemic level. Despite the well-characterized relationship between the nervous system and inflammation, the mechanism that links the different pathological features of fibromyalgia, including stress-related manifestations, central sensitization, and dysregulation of the innate and adaptive immune responses is largely unknown. This review aims to provide an overview of the current understanding of the role of adaptive immune cells, in particular T cells, in the physiopathology of fibromyalgia. It also aims at linking the latest advances emerging from basic science to envisage new perspectives to explain the role of $\mathrm{T}$ cells in interconnecting the psychological, neurological, and inflammatory symptoms of fibromyalgia.
\end{abstract}

Keywords: environmental sensitivity illnesses; immune responses; neuroimmunology; inflammation; pain; musculoskeletal diseases

\section{Background}

Fibromyalgia often comes to the attention of the orthopedic clinics because of the widespread chronic pain and musculoskeletal symptoms such as back and neck pain. The prevalence varies from $2 \%$ to $8 \%$ of the population [1]. The female:male ratio is $2: 1$ and can develop at any age, including in childhood. The prevalence is similar all over the world and industrialized countries do not have a higher prevalence. In a clinical setting, fibromyalgia is suspected in patients with multifocal pain not completely explained by inflammation or injury. In most cases, pain pathways throughout the body are amplified and musculoskeletal pain represents an important feature., The disease is also characterized by the presence of comorbidities, in particular chronic headaches, visceral pain, and sensory hyper-responsiveness, as well as psychiatric conditions such as depression and anxiety. Recently, it has been reported that in fibromyalgia patients, the presence of comorbid visceral pain such as irritable bowel syndrome is associated with increased severity of fibromyalgia symptoms [2].

The etiology of the disease is still not clear. Initially, fibromyalgia was defined as a chronic pain syndrome occurring in highly stressed individuals. Now it is known that there is not a single trigger [3-5] and the most defined pathological mechanism is the alteration of central pain pathways or 
central sensitization, associated with the amplification of the perception of pain even in the absence of the noxious stimuli. Moreover, emotional conditions can trigger or worsen symptoms [6-10]. Despite the well-known connection between the nervous system and inflammation, the mechanism that links the different pathological features of fibromyalgia, including stress-related manifestations, anxiety, central sensitization, and dysregulation of the inflammatory responses, is largely unknown.

In the early 1950s, the concept of neuroimmunology emerged that explored the crosstalk between immune cells and the nervous system. Over the decades, the role of the innate immunity in the onset of pain and stress-related manifestations has been partly characterized, whereas the role of the adaptive immune system is still poorly defined [11,12].

In fibromyalgia, the hypothalamic-pituitary-adrenal axis (HPA) is considered to play a role in the establishment of central sensitization [13,14].

It is known that the HPA axis controls response to stress and its activation leads to the secretion of corticotropin-releasing hormone (CRH), which modulates the immune response through the secretion of glucocorticoids. Patients with centralized pain syndromes can display hyper- or hypocortisolism and altered downstream signaling from the HPA axis. This includes increased infiltration of mast cells that also express receptors for CRH [13]. Release of granule from activated mast cells can lead to sensitization of peripheral and central nociceptors and the increase of pro-inflammatory cytokines $[8-10,15]$.

In patients with fibromyalgia, the levels of corticotropin-releasing hormone (CRH), were increased in the serum and cerebrospinal fluid and correlated with the severity of pain $[4,5,16,17]$. Accordingly, the stress response has been reported to worsen fibromyalgia syndrome and to augment the pain responses $[4,5]$. Moreover, animal models of cold, restraint, and sound stress can manifest behavioral and inflammatory dysregulation associated with hyperalgesia, similar to what is observed in fibromyalgia patients [18-20].

In addition to the regulation of stress and inflammatory response, the HPA axis and the sympathetic-adrenal-medullary axis are also involved in the modulation of adaptive immunity with different effects.

This review aims to provide an overview of the current understanding of the role of the cells of adaptive immunity, in particular $\mathrm{T}$ cells, in the physiopathology of fibromyalgia. It also aims at linking the latest advances emerging from basic science to envisage new perspectives that could explain the role of $\mathrm{T}$ cells in interconnecting the neurological and inflammatory symptoms of fibromyalgia.

\section{Inflammatory Mediators and Innate Immunity in the Generation of Pain in Fibromyalgia}

Recent research proposed that fibromyalgia could involve localized inflammation in the hypothalamus [6,7]. This perspective arises from the evidence that increased levels of proinflammatory chemokines such as IL-8 were found in the serum and cerebrospinal fluid of patients with fibromyalgia [21-24]. Chemokines, in this case, could directly assist nociception through the binding to chemokine receptors present along the pain pathway $[25,26]$. In addition to IL-8, the cytokines IL-1 $\beta$, TNF $\alpha$, IL- 6 , and IL-17 were also enhanced in serum and could contribute to the inflammatory response in the central nervous system [27]. In plasma, the increased IL-17 levels correlated with the levels of TNF $\alpha$, and IL-17 in cerebrospinal fluid and serum was found to correlate with pain and anxiety [28-30]. In addition, the serum level of IL-6 in patients was correlated with the pain score and, in animal models, the injection of IL-6, IL-1 $\beta$, and TNF $\alpha$ was shown to induce behavioral changes [15].

Pain in fibromyalgia involves neuroinflammatory processes triggered by mast cells and microglia [31-35]. Mounting evidence indeed supports the role of mast cells in fibromyalgia comorbid disorders and painful conditions [6,36,37]. For example, CCL11 (eotaxin) and CCL2 (a potent chemoattractant for mast cells), were found to be elevated in the plasma of fibromyalgia patients [38]. In rat models, CCL2 induced widespread chronic muscle pain through the activation of its receptor, CCR2, on the peripheral nerve terminals [39]. On the other hand, in vitro, myoblasts treated with CCL2 were shown to secrete significant amounts of the key pro-inflammatory cytokine IL-1 $\beta$ as well as CXCL10 [38] 
The role of mast cells in establishing pain has also been shown in a mouse model of postoperative pain, in which mast cell depletion prevented mechanical central pain sensitization [40].

In the interplay with mast cells, microglia which are the resident macrophages of the central nervous system, can have a role by increasing inflammation through the secretion of cytokines [41,42].

It has been proposed that CX3CL1 chemokine could represent the link between the signaling pathway of neuropathic pain and the immune responses. Soluble CX3CL1 is shed from primary afferent terminals and spinal neurons through the action of cathepsin $\mathrm{S}$, which is released by activated microglial cells. CX3CL1 could, in turn, stimulate microglia thus establishing positive feedback. Therefore it is possible that chemokines and cytokines secreted by activated microglia can be involved in establishing a state of neuronal hyperactivity and central sensitization [13,43-46]. Overall, microglia, through these mechanisms, can contribute to brain inflammation and to the pathogenesis of different brain disorders [41,47-52]. Together these studies underline the role of cells and mediators of the innate immunity in maintaining pain conditions such as musculoskeletal pain and central sensitization [53].

It is, however, important to note that a very novel finding in the transgenic experimental mouse model showed that nociceptor stimulation of peripheral sensory afferent neurons was able to induce IL-17 secretion by local TCR $\gamma \delta$ T cells and by CD4 ${ }^{+} \mathrm{T}$ cells [54]. Despite the increasing evidence in this field, the interconnections between the main symptoms of fibromyalgia, such as stress, anxiety, chronic musculoskeletal pain, and the adaptive immune responses still need an explanation.

\section{Role of T Cells in Fibromyalgia: Literature Data}

As compared to myalgic encephalomyelitis, in which the adaptive immune system has been described as a player in the pathogenesis, the association of fibromyalgia with infections and with the generation of cross-reactive antibodies is less clear and autoreactive immune responses are likely to play a less determinant role [55]. Nevertheless, changes in specific subsets of T cells have been reported in the literature even if the results are not conclusive.

The immune system can modulate the nervous system and vice versa. For example, the neurotransmitters, such as glutamate can trigger $\mathrm{T}$ cell functions and dopamine, gonadotrophin-releasing hormones, somatostatin, and substance $\mathrm{P}$, were shown to affect the phenotypic polarization of T cells [56]. Animal studies have enlightened the role of $\mathrm{T}$ cells in pain development. In particular, the depletion of $\mathrm{CD} 4^{+} \mathrm{T}$ cells in a mouse model was able to inhibit thermal hyperalgesia and tactile central sensitization following partial sciatic nerve ligation $[57,58]$.

Mice lacking $\mathrm{T}$ cells and mice lacking IFN $\gamma$, which is mainly expressed by $\mathrm{T}$ cells, showed significantly less mechanical hypersensitivity. This suggests that T-cells are involved in neuropathic pain and that IFN $\gamma$ plays a major role.

Furthermore, it has been shown that following injury, CD3, CD4, and CD8 T-cell markers were increased in female mice, more than in males. [59]. This latter finding underlines that $\mathrm{T}$ cells can be involved in pain development and should also be taken into account in the explanation of the female prevalence of fibromyalgia.

To clarify the potential role of T cells in fibromyalgia, we searched the PubMed database between 1960 and 2019 using search terms fibromyalgia and T cells (or lymphocytes). We found 28 articles. Only articles in English were selected; articles not directly addressing the issue of the involvement of T cells in fibromyalgia were excluded from the data extraction.

The first study on this topic referred to the altered interleukin-2 (IL-2) secretion in patients with primary fibromyalgia syndrome. IL-2 was chosen as an indicator of $\mathrm{CD} 4^{+}$response as it is secreted by $\mathrm{T}$ cells upon $\mathrm{T}$ cell receptor (TcR) stimulation and mediates $\mathrm{T}$ cell proliferation. The study was performed on isolated $\mathrm{CD}^{+} \mathrm{T}$ cells from 12 patients and control subjects. $\mathrm{CD} 4^{+} \mathrm{T}$ cells from patients required a higher concentration of the mitogen concanavalin A in order to reach optimal secretion of IL-2, thus indicating a lower response of $\mathrm{CD}^{+} \mathrm{T}$ cells from fibromyalgia patients to activating stimuli [60].

A subsequent study was performed on 65 patients with fibromyalgia, and lymphocyte subpopulations were analyzed, including $\mathrm{CD}^{+} \mathrm{T}$ cells, CD19 (B cells), CD16 (natural killer cells), CD4 ${ }^{+}$ 
T helper, and $\mathrm{CD}^{+}$cytotoxic T cells. The expression of the activation markers CD25, CD69, and CD71 on $\mathrm{T}$ cells was also evaluated. The results indicated that the number of $\mathrm{CD}^{+} \mathrm{T}$ cells expressing the activation markers CD69 and CD25 was decreased in patients with fibromyalgia, whereas the CD4/CD8 ratio was similar in patients and controls. [61]

It followed a clinical study designed to analyze the immunophenotype and killing activity of peripheral blood mononuclear cell subpopulations in patients at baseline and upon treatment with low-doses of human IFN $\alpha$. At baseline, 124 patients with fibromyalgia showed a higher percentage of T lymphocytes expressing the activation marker CD25 than healthy controls subjects. After IFN $\alpha$ treatment, the main difference observed was a decrease in the percentage of $\mathrm{CD} 4^{+} \mathrm{T}$ cells with activated phenotype (HLA-DR ${ }^{+} \mathrm{CD} 4^{+}$) in the circulation. [62].

Another cohort of patients diagnosed with fibromyalgia according to American College of Rheumatology criteria was studied for cell-mediated sensitivity to environmental chemicals. Memory $\mathrm{T}$ lymphocytes were analyzed for proliferation in vitro in response to different chemical substances. In patients with fibromyalgia, the authors observed a significantly higher $\mathrm{T}$ cell proliferation in response to aluminum, lead, and platinum; and to a low extent to cadmium and silicon [63]. This evidence is also supported by results from other studies, indicating that people who have a history of fibromyalgia showed increased levels of metals (e.g., mercury, cadmium, cobalt, iron), leading to the release of pro-inflammatory cytokines. In particular, exposure to mercury could be associated with fibromyalgia/myalgic encephalomyelitis in humans [64-67].

A different group showed that victims of post-traumatic stress disorders have higher circulating $\mathrm{T}$ lymphocytes and lower cortisol levels, thus suggesting a risk for the development of autoimmune diseases. Patients in this study showed increased T-cell counts, hyperreactive immune responses on standardized delayed cutaneous hypersensitivity tests, and higher immunoglobulin-M levels [68]. In line with the association with autoimmune diseases, there is also considerable evidence indicating that autoimmune thyroid disease is associated with fibromyalgia [69].

Importantly, a study by Kaufmann and coworkers examined the effect of pain and stress on lymphocyte numbers, the lymphocyte subpopulations, and the Th1/Th2 cytokine ratio in T cells. Analysis of lymphocyte subpopulations indicated a significant reduction in the numbers of cytotoxic $\mathrm{CD}^{+}$lymphocytes in chronic pain patients whereas the ratio CD4/CD8 was not significantly altered [3]. Even if the results were not conclusive, the study enlightens the importance of the variations in the distribution of $\mathrm{T}$ cell subpopulations as a consequence of chronic stress. A negative correlation was indeed evidenced between post-traumatic stress scores and the number of $\mathrm{CD} 8^{+} \mathrm{T}$ cells in patients with fibromyalgia.

In an attempt to define whether also genetic predisposing factors influencing the response to serotonin may associate with $\mathrm{T}$ cell dysregulation, the polymorphic promoter region of the serotonin transporter (5-HTTLPR) was analyzed in patients with fibromyalgia. Patients were subdivided on the basis of the presence of the two allelic forms of 5-HTTLPR (either in homozygosis or in heterozygosis) and were evaluated for salivary cortisol levels and the absolute number of leucocyte subsets, such as natural killer (NK) cells and activated T and B lymphocytes. All patients had reduced cortisol levels. The homozygote group for the long allelic variant had increased $\mathrm{CD} 44^{+} \mathrm{CD} 25^{\text {low }}$ activated $\mathrm{T}$ lymphocytes, and homozygotes for the short allelic variant displayed elevated CD4 ${ }^{+}$HLA-DR ${ }^{+}$ activated T lymphocytes [8]. This suggests that there are no clear differences in the activation state of $\mathrm{CD}^{+} \mathrm{T}$ cells in patients expressing the different allelic variants, but there is a general increase in $\mathrm{CD} 4^{+}$ $\mathrm{T}$ cells expressing intermediate or late activation markers in patients with fibromyalgia.

A more recent investigation on lymphocyte subsets in fibromyalgia analyzed Natural Killer $\mathrm{T}$ (NKT)-like $\mathrm{CD}^{+} \mathrm{CD}^{+} 6^{+}$cells as possible mediators in mental symptoms such as depression in 96 fibromyalgia patients with anxiety and depression. Analysis of the frequency in the different subgroups of depression in fibromyalgia patients showed significant differences and the use of antidepressants significantly altered the level of $\mathrm{CD}^{+} \mathrm{CD}^{2} 6^{+} \mathrm{NKT}$ cells [9]. 
Patients with fibromyalgia also had increased levels of the inflammatory chemokines CCL17, CXCL9, CCL22, and CXCL11, in addition to CCL11 [70]. Taken together, the higher level of cytokines and chemokines exerting their chemotactic activity on cells of both innate and adaptive immunity suggests that the establishment of fibromyalgia syndrome and systemic inflammation could involve both cells of the innate immunity and T cells $[70,71]$.

Analysis of the percentage of mucosal-associated invariant T (MAIT) cells in peripheral blood and cell surface marker expression in fibromyalgia patients showed a decrease in the MAIT cell population as compared to healthy control subjects. Among the cell surface antigens in MAIT cells, CCR7, the chemokine receptor which mediates the homing to the lymph nodes, and the CD27 T cell costimulatory molecule were significantly increased. By contrast, there was a decrease in the expression of the chemokine receptors, CCR4 and CXCR1, and of the NK receptor, NKp80. These results suggested that MAIT cells may have a phenotype that could result in an increase in the response and production of proinflammatory cytokines.

In these patients, the drug treatment interruption resulted in alteration of the expression of CCR4, CCR5, CXCR4, CD27, CD28, ICOS CD127 (IL-7 receptor alpha), CD94, NKp80, and the activation marker CD69 in MAIT cells [3,72].

A comprehensive study on the $\mathrm{T}$ cell compartment has been recently published by Guggino et al., focusing the attention on the role of $\mathrm{CD} 4^{+} \mathrm{T}$ cells subpopulations in the pathophysiology of fibromyalgia. In a cohort of 36 patients, analysis of the circulating $\mathrm{CD} 4^{+} \mathrm{T}$ cell subsets showed an increased Th1 type signature in fibromyalgia patients compared to controls. In $\mathrm{CD}^{+} \mathrm{T}$ cells stimulated with PMA-Ionomycin, there was a significant increase in IFN $\gamma$ and $\mathrm{TNF} \alpha$ production. Interestingly, in these patients, serum levels of TNF- $\alpha$ and IFN- $\gamma$ were also increased and correlated with disease severity.

Together, these results indicate the expansion of Th1 cell subpopulations and a general trend toward higher levels of inflammatory cytokine-producing $\mathrm{CD} 4^{+}$cells in subjects with fibromyalgia compared with those with unrelated diseases. These patients underwent hyperbaric oxygen therapy, which has been studied for analgesic effect in a model of nociceptive neuroinflammatory pain and has been used for the treatment of several pain conditions. Interestingly a significant reduction of circulating cells with Th1 phenotype was observed after therapy that was correlated with an improvement of the disease score. In these patients, serotonin levels in the serum were reduced and showed an inverse correlation with the disease severity [73].

Recently, research has emerged focusing on cannabinoids as immune-modulating agents with an effect on T-cells, B-cells, monocytes, and microglia. As cannabinoids can cause a general reduction in pro-inflammatory cytokine levels and an enhancement in anti-inflammatory cytokines, a putative role in the treatment of multiple sclerosis, inflammatory bowel disease, and fibromyalgia has been suggested [74,75].

Together, the literature data on the role of $\mathrm{T}$ cells in fibromyalgia are not conclusive (Table 1). Regarding the activation state, it is important to mention that the protocol used for surface marker detection, the cohort of patients, and the phase of the disease, as well as the pharmacological treatment, may affect the results as the expression of activation markers can be different in acute versus chronic phases. Overall the concept that mainly emerges from the analysis of the results of these studies is an increase in the function and percentage of $\mathrm{CD} 4^{+} \mathrm{T}$ cells with a Th1 signature in fibromyalgia patients.

It is unclear however how the changes in $\mathrm{T}$ lymphocyte subset distribution and in the activation state can be linked to stress and pain conditions and other fibromyalgia manifestations. At present, it is also unclear whether subgroups of patients with different comorbid diseases can display differences in the T cell subset distribution. Except for the work of Nugraha et al. analyzing the role of NKT-like cells in the development of psychiatric comorbidities and an earlier report, there are no clear indications in this direction $[9,76]$. It would be of interest to expand the knowledge in this field as it has been shown that comorbid diseases such as visceral pain could amplify fibromyalgia symptoms [2]. 
Table 1. Summary of literature data on T lymphocytes and fibromyalgia.

\begin{tabular}{|c|c|c|c|c|c|}
\hline Cell Subpopulation & Phenotype/Function & Change in FM & Effect of Treatment & Sample Size & References \\
\hline $\mathrm{CD}^{+} \mathrm{T}$ cells & ConA induced IL-2 secretion & reduction & NA & 12 & Hader et al. (1991) [60] \\
\hline $\mathrm{CD}^{+} \mathrm{T}$ cells & $\mathrm{CD} 69^{+}, \mathrm{CD} 25^{+}$activated & reduction & NA & 65 & Hernanz et al. (1994) [61] \\
\hline $\mathrm{CD}^{+} \mathrm{T}$ cells/NK cells & $\mathrm{CD}_{25}{ }^{+}$ & Increase & $\begin{array}{c}\text { Reduction of } \\
\mathrm{CD}^{+} \text {HLADR }^{+} \text {by low } \\
\text { doses IFN } \alpha\end{array}$ & 124 (baseline) & Russel et al. (1999) [62] \\
\hline $\mathrm{CD}^{+} \mathrm{T}$ cells & $\begin{array}{l}\text { Proliferation in response to } \\
\text { environmental chemicals }\end{array}$ & Increase & NA & 39 & Shaklin et al. (2000) [63] \\
\hline $\mathrm{T}$ cells & Number & $\begin{array}{l}\text { Increase and association with } \\
\text { autoimmune disease } \\
\text { posttraumatic stress disorder }\end{array}$ & NA & 2490 & $\begin{array}{c}\text { Boscarino et al. (2004) [68], } \\
\text { Tagoe et al. (2012) [69] }\end{array}$ \\
\hline $\mathrm{CD} 8^{+} \mathrm{T}$ cells & - & Reduction & NA & 22 & Kaufmann et al. (2007) [3] \\
\hline $\mathrm{CD}^{+} \mathrm{T}$ cells & $\mathrm{CD} 4^{+} \mathrm{CD} 25^{\text {low }}, \mathrm{CD}^{+} \mathrm{HLADR}^{+}$ & Increase & NA & 75 & Carvalho et al. (2008) [8] \\
\hline NKT cells & $\mathrm{CD}^{+} \mathrm{CD} 56^{+}$ & $\begin{array}{l}\text { Increased in patients with lower } \\
\text { depression scores }\end{array}$ & $\begin{array}{c}\text { Modulated by } \\
\text { antidepressant } 54\end{array}$ & 96 & Nugraha et al. (2013) [9] \\
\hline $\mathrm{T}$ cell chemokines & $\begin{array}{l}\text { CCl17, CXCL9, CCL22, } \\
\text { CXCL11, CCL11 }\end{array}$ & Increased in serum & NA & 17 & Garcia et al. (2014) [70] \\
\hline $\begin{array}{l}\text { Mucosal Associated } \\
\text { invariant T (MAIT) }\end{array}$ & $\begin{array}{l}\text { CD8 MAIT and NKp80, CCR4, } \\
\text { CCR7, CXCR1, CD69 }\end{array}$ & Increased & $\begin{array}{l}\text { Varied expression by } \\
\text { treatment interruption }\end{array}$ & 26 & Sugimoto et al. (2015) [72] \\
\hline $\mathrm{T}$ cells & $\begin{array}{c}\text { Apoptosis and } \\
\text { proinflammatory cytokines } \\
\text { secretion }\end{array}$ & - & $\begin{array}{c}\text { Reduction after } \\
\text { cannabinoids treatment }\end{array}$ & Review article & $\begin{array}{c}\text { Katchan et al. (2016) [74], } \\
\text { Katz et al. (2017) [75] }\end{array}$ \\
\hline $\mathrm{CD}^{+} \mathrm{T}$ cells & Th1 $\mathrm{IFN}^{+} / \mathrm{TNF}^{+}$ & Increased & $\begin{array}{c}\text { Reduced by hyperbaric } \\
\text { oxygen therapy }\end{array}$ & 36 & Guggino et al. (2019) [73] \\
\hline
\end{tabular}




\section{T Cell Mediated Immune Response in Fibromyalgia: New Perspectives}

An interesting perspective about the role of adaptive immunity in disease physiopathology has been provided by Shoenfeld and coworkers in one article of this collection. The authors proposed the hypothesis of an autoimmune nature of the disease. This hypothesis is based on the evidence that several features of fibromyalgia point towards an autoimmune component of the pathogenesis [43]. According to this view, both trauma and infection, which are common triggering events of autoimmunity, can also precede the onset of fibromyalgia [77]. The authors refer to data indicating that various pathogens such as Epstein-Barr virus, herpes simplex virus, known as risk factors for autoimmune diseases, are also involved in the etiology of fibromyalgia $[77,78]$. It has been reported that in some cases, fibromyalgia can be temporally associated with autoimmune syndrome induced by adjuvants and, similarly to other autoimmune diseases, it has a female predominance $[79,80]$.

The hypothesis is supported by a report describing the association of fibromyalgia with B58, DR5, and DR8 HLA alleles in 55 patients underlining the possibility of genetic susceptibility to the autoimmune responses [81]. HLA association, in particular, the association with HLA class II alleles, could point towards an involvement of $\mathrm{CD} 4^{+} \mathrm{T}$ cell and $\mathrm{B}$ cell-mediated antibody responses. Nevertheless, despite some indications pointing in this direction, the evidence of the involvement of autoimmunity among the pathogenic triggering events of fibromyalgia is still limited. [82,83].

The results and hypothesis underlying this view, however, enlighten the possibility that crossreactive responses, mediated by either $\mathrm{B}$ or $\mathrm{T}$ cells, can occur upon prolonged chronic pain and systemic inflammation. It is also likely that the development of cross-reactive responses to self-antigens by $\mathrm{B}$ and $\mathrm{T}$ can preferentially occur in genetically susceptible patients. Moreover, stress-related responses have been postulated to play a role in disease onset and favor the development of autoreactive responses $[84,85]$. The events linked to autoimmunity could occur as a side manifestation of prolonged pain and inflammation which finally leads to dysregulation of the adaptive immune compartment. However, if autoimmunity is a side component of the disease rather than one of the causative triggering events, what is the link between environmental stress, anxiety and the generation of adaptive immune responses that could finally give rise to autoreactive responses?

An alternative view that links environmental stress events, anxiety, and $\mathrm{T}$ cell responses comes from the very novel findings in the field of immunology.

A comprehensive and exhaustive study in a mouse model has been performed, showing that $\mathrm{CD} 4^{+}$ $\mathrm{T}$ cells are essential for the onset and development of stress-induced anxiety behaviors [86]. The authors examined the role of the adaptive immune system in stress-induced behavioral changes by exposing wild-type or immune-deficient mice to electronic foot shock [87-89]. The results indicate that adaptive immunity is required for the onset of anxiety-like stress-induced manifestations [90-95]. Consistent with previous reports, mice with acute stress exposure had significantly increased frequencies of peripheral $\mathrm{CD}^{+}$and $\mathrm{CD} 8^{+} \mathrm{T}$ cells compared to non-treated controls [96,97]. Depletion of $\mathrm{CD}^{+}$or $\mathrm{CD}^{+} \mathrm{T}$ cells before exposure to electronic foot shock demonstrated that only depletion of $\mathrm{CD} 4^{+} \mathrm{T}$ cells significantly reversed the stress-induced anxiety-like behavior. Importantly adoptive transfer of $\mathrm{CD}^{+} \mathrm{T}$ cells from mice exposed to stress into unexposed recipient mice induced a similar form of anxiety-like behavior.

RNA sequencing in $\mathrm{CD}^{+} \mathrm{T}$ cells from stress-exposed mice showed variation in the expression of genes encoding mitochondrial proteins. The authors concluded that stress exposure induces marked mitochondrial fission in peripheral $\mathrm{CD}^{+} \mathrm{T}$ cells associated with abnormal mitochondrial morphology and metabolic dysfunction. Analysis of the effects of critical components of the inflammatory response such as leukotriene B4 (LTB4) and PGE2 showed that LTB4 administration was capable of inducing anxiety-like behavior, which was reversed in part by the removal of $\mathrm{CD} 4^{+} \mathrm{T}$ cells. LTB4 was also capable of inducing mitochondrial fission in $\mathrm{CD}^{+} \mathrm{T}$ cells in vitro and could trigger mitochondrial fission in peripheral $\mathrm{CD}^{+} \mathrm{T}$ cells in vivo. Mitochondrial fission, in turn, stimulated ex novo xanthine synthesis by $\mathrm{CD}^{+}{ }^{+} \mathrm{T}$ cells through the induction of transcription factor IRF-1 [98]. IRF-1 accumulation in $\mathrm{CD}^{+}$ $\mathrm{T}$ cells is involved in Th1 development and in the maturation of $\mathrm{CD} 8^{+} \mathrm{T}$-cells. It is also involved 
in the differentiation and maturation of dendritic cells and in the inhibition of the development of regulatory T (Treg) cells [99-101]. On the other hand, patients with immune-mediated diseases such as inflammatory bowel disease showed dysregulated $\mathrm{T}$ cell proliferation, which can lead to anxiety-like behavior [102].

This very novel mechanism that remarkably links environmental stress and related mood disorders with $\mathrm{CD}^{+} \mathrm{T}$ cell altered functions through mitochondrial fission induced by mediators of inflammation may provide new keys of interpretation for fibromyalgia, which has a debated nature between psychogenic and rheumatic.

It is possible to speculate that the controversial nature of the disease and the association with anxiety and mood disorders, as well as the described association with increased activation of the CD4 ${ }^{+}$ compartment, could be linked by a mechanism that involves stress-induced mitochondrial alterations, metabolic dysregulation, and increased Th1 polarization.

\section{Concluding Remarks}

Analysis of literature data provides non-conclusive results on the role of $\mathrm{T}$ cells in the development and maintenance of fibromyalgia symptoms. However, it also emerges that in most cases, altered frequency and/or polarization of $\mathrm{T}$ cells mainly in the $\mathrm{CD} 4^{+} \mathrm{T}$ cell compartment is observed in patients. The presence of immune-mediated comorbid disease, the detection of autoantibodies and the female prevalence together with data suggesting an association with viral infections have suggested that, in some patients, autoimmune responses occur. However, it is also possible that autoimmunity may represent a side event to the primary alteration of the central pain pathways that finally results in the increase of inflammatory mediators at systemic level. A possible novel key of interpretation may come from recent findings in the field of experimental immunology, providing an intriguing explanation to the link between stress-induced behavioral changes and metabolic and functional alteration in CD4 $\mathrm{T}$ cells. These new perspectives may suggest an alternative view that envisages the involvement of variation of the $T$ reactivity beyond the classical antigen-induced activation. This could explain both literature data enlightening alteration of the $\mathrm{T}$ cell compartments without providing evidence of $\mathrm{T}$ cell responses as main triggering events in fibromyalgia. It may also outline new possible solutions to the controversies about the psychogenic and rheumatic nature of the disease. The data available in the literature and the new perspectives in the field also encourage scientists to apply alternative strategies and advanced technologies for the analysis of the different subsets of T cells. This could shed light on stress-induced morphological changes and metabolic dysfunction that may result in a generalized hyper-activation in the T cell compartment.

Funding: This work was funded by the Italian Ministry of Health.

Acknowledgments: We thank Francesca Granucci and Laura Gornati, University of Milano-Bicocca, Milan, Italy, for the helpful discussion.

Conflicts of Interest: The authors declare no conflict of interest.

\section{References}

1. Clauw, D.J. Fibromyalgia: A clinical review. JAMA 2014, 311, 1547-1555. [CrossRef]

2. Costantini, R.; Affaitati, G.; Wesselmann, U.; Czakanski, P.; Giamberardino, M.A. Visceral pain as a triggering factor for fibromyalgia symptoms in comorbid patients. Pain 2017, 158, 1925-1937. [CrossRef] [PubMed]

3. Kaufmann, I.; Eisner, C.; Richter, P.; Huge, V.; Beyer, A.; Chouker, A.; Schelling, G.; Thiel, M. Lymphocyte subsets and the role of TH1/TH2 balance in stressed chronic pain patients. Neuroimmunomodulation 2007, 14, 272-280. [CrossRef] [PubMed]

4. Bote, M.E.; Garcia, J.J.; Hinchado, M.D.; Ortega, E. Fibromyalgia: Anti-inflammatory and stress responses after acute moderate exercise. PLOS ONE 2013, 8, e74524. [CrossRef] [PubMed]

5. Bote, M.E.; Garcia, J.J.; Hinchado, M.D.; Ortega, E. Inflammatory/stress feedback dysregulation in women with fibromyalgia. Neuroimmunomodulation 2012, 19, 343-351. [CrossRef] [PubMed] 
6. Theoharides, T.C.; Tsilioni, I.; Bawazeer, M. Mast Cells, Neuroinflammation and Pain in Fibromyalgia Syndrome. Front. Cell. Neurosci. 2019, 13, 353. [CrossRef]

7. Theoharides, T.C.; Tsilioni, I.; Arbetman, L.; Panagiotidou, S.; Stewart, J.M.; Gleason, R.M.; Russell, I.J. Fibromyalgia syndrome in need of effective treatments. J. Pharmacol. Exp. Ther. 2015, 355, 255-263. [CrossRef]

8. Carvalho, L.S.; Correa, H.; Silva, G.C.; Campos, F.S.; Baiao, F.R.; Ribeiro, L.S.; Faria, A.M.; d'Avila Reis, D. May genetic factors in fibromyalgia help to identify patients with differentially altered frequencies of immune cells? Clin. Exp. Immunol. 2008, 154, 346-352. [CrossRef]

9. Nugraha, B.; Korallus, C.; Kielstein, H.; Gutenbrunner, C. CD3+CD56+natural killer T cells in fibromyalgia syndrome patients: Association with the intensity of depression. Clin. Exp. Rheumatol. 2013, 31, S9-S15.

10. Uceyler, N.; Hauser, W.; Sommer, C. Systematic review with meta-analysis: Cytokines in fibromyalgia syndrome. BMC Musculoskelet. Disord. 2011, 12, 245. [CrossRef]

11. Filiano, A.J.; Xu, Y.; Tustison, N.J.; Marsh, R.L.; Baker, W.; Smirnov, I.; Overall, C.C.; Gadani, S.P.; Turner, S.D.; Weng, Z.; et al. Unexpected role of interferon-gamma in regulating neuronal connectivity and social behaviour. Nature 2016, 535, 425-429. [CrossRef] [PubMed]

12. Kipnis, J. Multifaceted interactions between adaptive immunity and the central nervous system. Science 2016, 353, 766-771. [CrossRef] [PubMed]

13. Totsch, S.K.; Sorge, R.E. Immune System Involvement in Specific Pain Conditions. Mol. Pain $2017,13$. [CrossRef]

14. Eller-Smith, O.C.; Nicol, A.L.; Christianson, J.A. Potential Mechanisms Underlying Centralized Pain and Emerging Therapeutic Interventions. Front. Cell. Neurosci. 2018, 12, 35. [CrossRef]

15. Bazzichi, L.; Rossi, A.; Massimetti, G.; Giannaccini, G.; Giuliano, T.; De Feo, F.; Ciapparelli, A.; Dell'Osso, L.; Bombardieri, S. Cytokine patterns in fibromyalgia and their correlation with clinical manifestations. Clin. Exp. Rheumatol. 2007, 25, 225-230. [PubMed]

16. Tsilioni, I.; Russell, I.J.; Stewart, J.M.; Gleason, R.M.; Theoharides, T.C. Neuropeptides CRH, SP, HK-1, and Inflammatory Cytokines IL-6 and TNF Are Increased in Serum of Patients with Fibromyalgia Syndrome, Implicating Mast Cells. J. Pharmacol. Exp. Ther. 2016, 356, 664-672. [CrossRef]

17. McLean, S.A.; Williams, D.A.; Stein, P.K.; Harris, R.E.; Lyden, A.K.; Whalen, G.; Park, K.M.; Liberzon, I.; Sen, A.; Gracely, R.H.; et al. Cerebrospinal fluid corticotropin-releasing factor concentration is associated with pain but not fatigue symptoms in patients with fibromyalgia. Neuropsychopharmacology 2006, 31, 2776-2782. [CrossRef]

18. Nishiyori, M.; Ueda, H. Prolonged gabapentin analgesia in an experimental mouse model of fibromyalgia. Mol. Pain 2008, 4, 52. [CrossRef]

19. Bardin, L.; Malfetes, N.; Newman-Tancredi, A.; Depoortere, R. Chronic restraint stress induces mechanical and cold allodynia, and enhances inflammatory pain in rat: Relevance to human stress-associated painful pathologies. Behav. Brain Res. 2009, 205, 360-366. [CrossRef]

20. Chen, X.; Green, P.G.; Levine, J.D. Stress enhances muscle nociceptor activity in the rat. Neuroscience 2011, 185, 166-173. [CrossRef]

21. Andres-Rodriguez, L.; Borras, X. Machine Learning to Understand the Immune-Inflammatory Pathways in Fibromyalgia. Int. J. Mol. Sci. 2019, 20, 4231. [CrossRef] [PubMed]

22. Ross, R.L.; Jones, K.D.; Bennett, R.M.; Ward, R.L.; Druker, B.J.; Wood, L.J. Preliminary Evidence of Increased Pain and Elevated Cytokines in Fibromyalgia Patients with Defective Growth Hormone Response to Exercise. Open Immunol. J. 2010, 3, 9-18. [CrossRef] [PubMed]

23. Kadetoff, D.; Lampa, J.; Westman, M.; Andersson, M.; Kosek, E. Evidence of central inflammation in fibromyalgia-increased cerebrospinal fluid interleukin-8 levels. J. Neuroimmunol. 2012, 242, 33-38. [CrossRef]

24. Rodriguez-Pinto, I.; Agmon-Levin, N.; Howard, A.; Shoenfeld, Y. Fibromyalgia and cytokines. Immunol. Lett. 2014, 161, 200-203. [CrossRef]

25. Abbadie, C. Chemokines, chemokine receptors and pain. Trends Immunol. 2005, 26, 529-534. [CrossRef]

26. Charo, I.F.; Ransohoff, R.M. The many roles of chemokines and chemokine receptors in inflammation. N Engl. J. Med. 2006, 354, 610-621. [CrossRef]

27. Romero-Sanchez, C.; Tsou, H.K.; Jan, M.S.; Wong, R.H.; Chang, I.C.; Londono, J.; Valle-Onate, R.; Howe, H.S.; $\mathrm{Yu}$, D.; Leung, B.P.; et al. Serum monocyte chemotactic protein-1 concentrations distinguish patients with ankylosing spondylitis from patients with mechanical low back pain. J. Spinal Disord. Tech. 2011, 24, $202-207$. [CrossRef] 
28. Pernambuco, A.P.; Schetino, L.P.; Alvim, C.C.; Murad, C.M.; Viana, R.S.; Carvalho, L.S.; Reis, D.A. Increased levels of IL-17A in patients with fibromyalgia. Clin. Exp. Rheumatol. 2013, 31, S60-S63.

29. Liu, Y.; Ho, R.C.; Mak, A. The role of interleukin (IL)-17 in anxiety and depression of patients with rheumatoid arthritis. Int. J. Rheum. Dis. 2012, 15, 183-187. [CrossRef]

30. Meng, X.; Zhang, Y.; Lao, L.; Saito, R.; Li, A.; Backman, C.M.; Berman, B.M.; Ren, K.; Wei, P.K.; Zhang, R.X. Spinal interleukin-17 promotes thermal hyperalgesia and NMDA NR1 phosphorylation in an inflammatory pain rat model. Pain 2013, 154, 294-305. [CrossRef]

31. Kim, H.; Kim, J.; Loggia, M.L.; Cahalan, C.; Garcia, R.G.; Vangel, M.G.; Wasan, A.D.; Edwards, R.R.; Napadow, V. Fibromyalgia is characterized by altered frontal and cerebellar structural covariance brain networks. Neuroimage Clin. 2015, 7, 667-677. [CrossRef]

32. Kissel, C.L.; Kovacs, K.J.; Larson, A.A. Evidence for the modulation of nociception in mice by central mast cells. Eur. J. Pain 2017, 21, 1743-1755. [CrossRef] [PubMed]

33. Alfonso Romero-Sandoval, E.; Sweitzer, S. Nonneuronal central mechanisms of pain: Glia and immune response. Prog. Mol. Biol. Transl. Sci. 2015, 131, 325-358. [CrossRef] [PubMed]

34. Heron, A.; Dubayle, D. A focus on mast cells and pain. J. Neuroimmunol. 2013, 264, 1-7. [CrossRef]

35. Chatterjea, D.; Martinov, T. Mast cells: Versatile gatekeepers of pain. Mol. Immunol. 2015, 63, 38-44. [CrossRef] [PubMed]

36. Torresani, C.; Bellafiore, S.; De Panfilis, G. Chronic urticaria is usually associated with fibromyalgia syndrome. Acta Derm. Venereol. 2009, 89, 389-392. [CrossRef]

37. Blanco, I.; Beritze, N.; Arguelles, M.; Carcaba, V.; Fernandez, F.; Janciauskiene, S.; Oikonomopoulou, K.; de Serres, F.J.; Fernandez-Bustillo, E.; Hollenberg, M.D. Abnormal overexpression of mastocytes in skin biopsies of fibromyalgia patients. Clin. Rheumatol. 2010, 29, 1403-1412. [CrossRef]

38. Zhang, Z.; Cherryholmes, G.; Mao, A.; Marek, C.; Longmate, J.; Kalos, M.; Amand, R.P.; Shively, J.E. High plasma levels of MCP-1 and eotaxin provide evidence for an immunological basis of fibromyalgia. Exp. Biol. Med. (Maywood) 2008, 233, 1171-1180. [CrossRef]

39. Alvarez, P.; Green, P.G.; Levine, J.D. Role for monocyte chemoattractant protein-1 in the induction of chronic muscle pain in the rat. Pain 2014, 155, 1161-1167. [CrossRef]

40. Oliveira, S.M.; Drewes, C.C.; Silva, C.R.; Trevisan, G.; Boschen, S.L.; Moreira, C.G.; de Almeida Cabrini, D.; Da Cunha, C.; Ferreira, J. Involvement of mast cells in a mouse model of postoperative pain. Eur. J. Pharmacol. 2011, 672, 88-95. [CrossRef]

41. Aguzzi, A.; Barres, B.A.; Bennett, M.L. Microglia: Scapegoat, saboteur, or something else? Science 2013, 339, 156-161. [CrossRef]

42. Kawahara, K.; Hohjoh, H.; Inazumi, T.; Tsuchiya, S.; Sugimoto, Y. Prostaglandin E2-induced inflammation: Relevance of prostaglandin E receptors. Biochim. Biophys. Acta 2015, 1851, 414-421. [CrossRef] [PubMed]

43. Ryabkova, V.A.; Churilov, L.P.; Shoenfeld, Y. Neuroimmunology: What Role for Autoimmunity, Neuroinflammation, and Small Fiber Neuropathy in Fibromyalgia, Chronic Fatigue Syndrome, and Adverse Events after Human Papillomavirus Vaccination? Int. J. Mol. Sci. 2019, 20, 5164. [CrossRef] [PubMed]

44. Backryd, E.; Tanum, L.; Lind, A.L.; Larsson, A.; Gordh, T. Evidence of both systemic inflammation and neuroinflammation in fibromyalgia patients, as assessed by a multiplex protein panel applied to the cerebrospinal fluid and to plasma. J. Pain Res. 2017, 10, 515-525. [CrossRef] [PubMed]

45. Dong, H.; Zhang, X.; Wang, Y.; Zhou, X.; Qian, Y.; Zhang, S. Suppression of Brain Mast Cells Degranulation Inhibits Microglial Activation and Central Nervous System Inflammation. Mol. Neurobiol. 2017, 54, 997-1007. [CrossRef] [PubMed]

46. Zhang, X.; Wang, Y.; Dong, H.; Xu, Y.; Zhang, S. Induction of Microglial Activation by Mediators Released from Mast Cells. Cell. Physiol. Biochem. 2016, 38, 1520-1531. [CrossRef]

47. Reu, P.; Khosravi, A.; Bernard, S.; Mold, J.E.; Salehpour, M.; Alkass, K.; Perl, S.; Tisdale, J.; Possnert, G.; Druid, H.; et al. The Lifespan and Turnover of Microglia in the Human Brain. Cell Rep. 2017, 20, 779-784. [CrossRef]

48. Groh, J.; Martini, R. Neuroinflammation as modifier of genetically caused neurological disorders of the central nervous system: Understanding pathogenesis and chances for treatment. Gila 2017, 65, 1407-1422. [CrossRef]

49. Wang, W.; Ji, P.; Riopelle, R.J.; Dow, K.E. Functional expression of corticotropin-releasing hormone (CRH) receptor 1 in cultured rat microglia. J. Neurochem. 2002, 80, 287-294. [CrossRef] 
50. Thonhoff, J.R.; Simpson, E.P.; Appel, S.H. Neuroinflammatory mechanisms in amyotrophic lateral sclerosis pathogenesis. Curr. Opin. Neurol. 2018, 31, 635-639. [CrossRef]

51. Hansson, E. Long-term pain, neuroinflammation and glial activation. Scand. J. Pain 2010, 1, 67-72. [CrossRef] [PubMed]

52. Blaszczyk, L.; Maitre, M.; Leste-Lasserre, T.; Clark, S.; Cota, D.; Oliet, S.H.R.; Fenelon, V.S. Sequential alteration of microglia and astrocytes in the rat thalamus following spinal nerve ligation. J. Neuroinflammation 2018, 15, 349. [CrossRef] [PubMed]

53. Skaper, S.D.; Facci, L.; Zusso, M.; Giusti, P. An Inflammation-Centric View of Neurological Disease: Beyond the Neuron. Front. Cell. Neurosci. 2018, 12, 72. [CrossRef] [PubMed]

54. Cohen, J.A.; Edwards, T.N.; Liu, A.W.; Hirai, T.; Jones, M.R.; Wu, J.; Li, Y.; Zhang, S.; Ho, J.; Davis, B.M.; et al. Cutaneous TRPV1(+) Neurons Trigger Protective Innate Type 17 Anticipatory Immunity. Cell 2019, 178, 919-932. [CrossRef]

55. Sotzny, F.; Blanco, J.; Capelli, E.; Castro-Marrero, J.; Steiner, S.; Murovska, M.; Scheibenbogen, C.; European Network on, M.C. Myalgic Encephalomyelitis/Chronic Fatigue Syndrome-Evidence for an autoimmune disease. Autoimmun. Rev. 2018, 17, 601-609. [CrossRef]

56. Ganor, Y.; Besser, M.; Ben-Zakay, N.; Unger, T.; Levite, M. Human T cells express a functional ionotropic glutamate receptor GluR3, and glutamate by itself triggers integrin-mediated adhesion to laminin and fibronectin and chemotactic migration. J. Immunol. 2003, 170, 4362-4372. [CrossRef]

57. Kobayashi, Y.; Kiguchi, N.; Fukazawa, Y.; Saika, F.; Maeda, T.; Kishioka, S. Macrophage-T cell interactions mediate neuropathic pain through the glucocorticoid-induced tumor necrosis factor ligand system. J. Biol. Chem. 2015, 290, 12603-12613. [CrossRef]

58. Draleau, K.; Maddula, S.; Slaiby, A.; Nutile-McMenemy, N.; De Leo, J.; Cao, L. Phenotypic Identification of Spinal Cord-Infiltrating CD4(+) T Lymphocytes in a Murine Model of Neuropathic Pain. J. Pain Relief 2014. [CrossRef]

59. Sorge, R.E.; Mapplebeck, J.C.; Rosen, S.; Beggs, S.; Taves, S.; Alexander, J.K.; Martin, L.J.; Austin, J.S.; Sotocinal, S.G.; Chen, D.; et al. Different immune cells mediate mechanical pain hypersensitivity in male and female mice. Nat. Neurosci. 2015, 18, 1081-1083. [CrossRef]

60. Hader, N.; Rimon, D.; Kinarty, A.; Lahat, N. Altered interleukin-2 secretion in patients with primary fibromyalgia syndrome. Arthritis Rheum. 1991, 34, 866-872. [CrossRef]

61. Hernanz, W.; Valenzuela, A.; Quijada, J.; Garcia, A.; de la Iglesia, J.L.; Gutierrez, A.; Povedano, J.; Moreno, I.; Sanchez, B. Lymphocyte subpopulations in patients with primary fibromyalgia. J. Rheumatol. 1994, 21, 2122-2124.

62. Russell, I.J.; Vipraio, G.A.; Michalek, J.E.; Craig, F.E.; Kang, Y.K.; Richards, A.B. Lymphocyte markers and natural killer cell activity in fibromyalgia syndrome: Effects of low-dose, sublingual use of human interferon-alpha. J. Interferon Cytokine Res. 1999, 19, 969-978. [CrossRef] [PubMed]

63. Shanklin, D.R.; Stevens, M.V.; Hall, M.F.; Smalley, D.L. Environmental immunogens and T-cell-mediated responses in fibromyalgia: Evidence for immune dysregulation and determinants of granuloma formation. Exp. Mol. Pathol. 2000, 69, 102-118. [CrossRef] [PubMed]

64. Bjorklund, G.; Dadar, M.; Aaseth, J. Delayed-type hypersensitivity to metals in connective tissue diseases and fibromyalgia. Environ. Res. 2018, 161, 573-579. [CrossRef] [PubMed]

65. Stejskal, V. Metals as a common trigger of inflammation resulting in non-specific symptoms: Diagnosis and treatment. Isr. Med. Assoc. J. 2014, 16, 753-758.

66. Stejskal, V.; Ockert, K.; Bjorklund, G. Metal-induced inflammation triggers fibromyalgia in metal-allergic patients. Neuro Endocrinol. Lett. 2013, 34, 559-565.

67. Pigatto, P.D.; Minoia, C.; Ronchi, A.; Brambilla, L.; Ferrucci, S.M.; Spadari, F.; Passoni, M.; Somalvico, F.; Bombeccari, G.P.; Guzzi, G. Allergological and toxicological aspects in a multiple chemical sensitivity cohort. Oxid. Med. Cell. Longev. 2013, 2013, 356235. [CrossRef]

68. Boscarino, J.A. Posttraumatic stress disorder and physical illness: Results from clinical and epidemiologic studies. Ann. N. Y. Acad. Sci. 2004, 1032, 141-153. [CrossRef]

69. Tagoe, C.E.; Zezon, A.; Khattri, S. Rheumatic manifestations of autoimmune thyroid disease: The other autoimmune disease. J. Rheumatol. 2012, 39, 1125-1129. [CrossRef]

70. Garcia, J.J.; Cidoncha, A.; Bote, M.E.; Hinchado, M.D.; Ortega, E. Altered profile of chemokines in fibromyalgia patients. Ann. Clin. Biochem. 2014, 51, 576-581. [CrossRef] 
71. Imamura, M.; Targino, R.A.; Hsing, W.T.; Imamura, S.; Azevedo, R.S.; Boas, L.S.; Tozetto-Mendoza, T.R.; Alfieri, F.M.; Filippo, T.R.; Battistella, L.R. Concentration of cytokines in patients with osteoarthritis of the knee and fibromyalgia. Clin. Interv. Aging 2014, 9, 939-944. [CrossRef]

72. Sugimoto, C.; Konno, T.; Wakao, R.; Fujita, H.; Fujita, H.; Wakao, H. Mucosal-associated invariant T cell is a potential marker to distinguish fibromyalgia syndrome from arthritis. PLoS ONE 2015, 10, e0121124. [CrossRef]

73. Guggino, G.; Schinocca, C.; Lo Pizzo, M.; Di Liberto, D.; Garbo, D.; Raimondo, S.; Alessandro, R.; Brighina, F.; Ruscitti, P.; Giacomelli, R.; et al. T helper 1 response is correlated with widespread pain, fatigue, sleeping disorders and the quality of life in patients with fibromyalgia and is modulated by hyperbaric oxygen therapy. Clin. Exp. Rheumatol. 2019, 37, 81-89.

74. Katchan, V.; David, P.; Shoenfeld, Y. Cannabinoids and autoimmune diseases: A systematic review. Autoimmun. Rev. 2016, 15, 513-528. [CrossRef]

75. Katz, D.; Katz, I.; Porat-Katz, B.S.; Shoenfeld, Y. Medical cannabis: Another piece in the mosaic of autoimmunity? Clin. Pharmacol. Ther. 2017, 101, 230-238. [CrossRef]

76. Bonaccorso, S.; Lin, A.H.; Verkerk, R.; Van Hunsel, F.; Libbrecht, I.; Scharpe, S.; DeClerck, L.; Biondi, M.; Janca, A.; Maes, M. Immune markers in fibromyalgia: Comparison with major depressed patients and normal volunteers. J. Affect. Disord. 1998, 48, 75-82. [CrossRef]

77. Buskila, D.; Atzeni, F.; Sarzi-Puttini, P. Etiology of fibromyalgia: The possible role of infection and vaccination. Autoimmun. Rev. 2008, 8, 41-43. [CrossRef]

78. Pridgen, W.L.; Duffy, C.; Gendreau, J.F.; Gendreau, R.M. A famciclovir + celecoxib combination treatment is safe and efficacious in the treatment of fibromyalgia. J. Pain Res. 2017, 10, 451-460. [CrossRef]

79. Khoo, T.; Proudman, S.; Limaye, V. Silicone breast implants and depression, fibromyalgia and chronic fatigue syndrome in a rheumatology clinic population. Clin. Rheumatol. 2019, 38, 1271-1276. [CrossRef]

80. Wolfe, F.; Walitt, B.; Perrot, S.; Rasker, J.J.; Hauser, W. Fibromyalgia diagnosis and biased assessment: Sex, prevalence and bias. PLoS ONE 2018, 13, e0203755. [CrossRef]

81. Branco, J.C.; Tavares, V.; Abreu, I.; Correia, M.M.; Caetano, J.A.M. HLA Studies in Fibromyalgia. J. Musculoskelet. Pain 1996, 4, 21-27. [CrossRef]

82. Horven, S.; Stiles, T.C.; Holst, A.; Moen, T. HLA antigens in primary fibromyalgia syndrome. J. Rheumatol. 1992, 19, 1269-1270.

83. Biasi, G.; Fioravanti, A.; Galeazzi, M.; Marcolongo, R. Absence of correlation between HLA antigens and fibromyalgia syndrome in Italian patients. Ann. Ital. Med. Int. 1994, 9, $228-230$.

84. Glaser, R.; Kiecolt-Glaser, J.K. Stress-induced immune dysfunction: Implications for health. Nat. Rev. Immunol. 2005, 5, 243-251. [CrossRef]

85. Padgett, D.A.; Glaser, R. How stress influences the immune response. Trends Immunol. 2003, 24, 444-448. [CrossRef]

86. Fan, K.Q.; Li, Y.Y.; Wang, H.L.; Mao, X.T.; Guo, J.X.; Wang, F.; Huang, L.J.; Li, Y.N.; Ma, X.Y.; Gao, Z.J.; et al. Stress-Induced Metabolic Disorder in Peripheral CD4(+) T Cells Leads to Anxiety-like Behavior. Cell 2019, 179, 864-879. [CrossRef]

87. Bourin, M.; Petit-Demouliere, B.; Dhonnchadha, B.N.; Hascoet, M. Animal models of anxiety in mice. Fundam. Clin. Pharmacol. 2007, 21,567-574. [CrossRef]

88. Campos, A.C.; Fogaca, M.V.; Aguiar, D.C.; Guimaraes, F.S. Animal models of anxiety disorders and stress. Braz. J. Psychiatry 2013, 35, S101-S111. [CrossRef]

89. Steimer, T. Animal models of anxiety disorders in rats and mice: Some conceptual issues. Dialogues Clin. Neurosci. 2011, 13, 495-506.

90. Beurel, E.; Harrington, L.E.; Jope, R.S. Inflammatory T helper 17 cells promote depression-like behavior in mice. Biol. Psychiatry 2013, 73, 622-630. [CrossRef]

91. Beurel, E.; Lowell, J.A. Th17 cells in depression. Brain Behav. Immun. 2018, 69, 28-34. [CrossRef] [PubMed]

92. Clark, S.M.; Michael, K.C.; Klaus, J.; Mert, A.; Romano-Verthelyi, A.; Sand, J.; Tonelli, L.H. Dissociation between sickness behavior and emotionality during lipopolysaccharide challenge in lymphocyte deficient Rag2(-/-) mice. Behav. Brain Res. 2015, 278, 74-82. [CrossRef] [PubMed]

93. Clark, S.M.; Sand, J.; Francis, T.C.; Nagaraju, A.; Michael, K.C.; Keegan, A.D.; Kusnecov, A.; Gould, T.D.; Tonelli, L.H. Immune status influences fear and anxiety responses in mice after acute stress exposure. Brain Behav. Immun. 2014, 38, 192-201. [CrossRef] [PubMed] 
94. Rattazzi, L.; Piras, G.; Ono, M.; Deacon, R.; Pariante, C.M.; D'Acquisto, F. CD4(+) but not CD8(+) T cells revert the impaired emotional behavior of immunocompromised RAG-1-deficient mice. Transl. Psychiatry 2013, 3, e280. [CrossRef] [PubMed]

95. Miyajima, M.; Zhang, B.; Sugiura, Y.; Sonomura, K.; Guerrini, M.M.; Tsutsui, Y.; Maruya, M.; Vogelzang, A.; Chamoto, K.; Honda, K.; et al. Metabolic shift induced by systemic activation of T cells in PD-1-deficient mice perturbs brain monoamines and emotional behavior. Nat. Immunol. 2017, 18, 1342-1352. [CrossRef]

96. Dhabhar, F.S. Enhancing versus Suppressive Effects of Stress on Immune Function: Implications for Immunoprotection versus Immunopathology. Allergy Asthma Clin. Immunol. 2008, 4, 2-11. [CrossRef]

97. Dragos, D.; Tanasescu, M.D. The effect of stress on the defense systems. J. Med. Life 2010, 3, 10-18.

98. Gao, Z.; Li, Y.; Wang, F.; Huang, T.; Fan, K.; Zhang, Y.; Zhong, J.; Cao, Q.; Chao, T.; Jia, J.; et al. Mitochondrial dynamics controls anti-tumour innate immunity by regulating CHIP-IRF1 axis stability. Nat. Commun. 2017, 8, 1805. [CrossRef]

99. Fragale, A.; Gabriele, L.; Stellacci, E.; Borghi, P.; Perrotti, E.; Ilari, R.; Lanciotti, A.; Remoli, A.L.; Venditti, M.; Belardelli, F.; et al. IFN regulatory factor-1 negatively regulates CD4+ CD25+ regulatory T cell differentiation by repressing Foxp3 expression. J. Immunol. 2008, 181, 1673-1682. [CrossRef]

100. Gabriele, L.; Fragale, A.; Borghi, P.; Sestili, P.; Stellacci, E.; Venditti, M.; Schiavoni, G.; Sanchez, M.; Belardelli, F.; Battistini, A. IRF-1 deficiency skews the differentiation of dendritic cells toward plasmacytoid and tolerogenic features. J. Leukoc. Biol. 2006, 80, 1500-1511. [CrossRef]

101. Buccione, C.; Fragale, A.; Polverino, F.; Ziccheddu, G.; Arico, E.; Belardelli, F.; Proietti, E. Role of interferon regulatory factor 1 in governing Treg depletion, Th1 polarization, inflammasome activation and antitumor efficacy of cyclophosphamide. Int. J. Cancer 2018, 142, 976-987. [CrossRef] [PubMed]

102. Gracie, D.J.; Ford, A.C. Depression, Antidepressants, and Inflammatory Bowel Disease: Implications for Future Models of Care. Gastroenterology 2019, 156, 2345-2347. [CrossRef] [PubMed]

(C) 2020 by the authors. Licensee MDPI, Basel, Switzerland. This article is an open access article distributed under the terms and conditions of the Creative Commons Attribution (CC BY) license (http://creativecommons.org/licenses/by/4.0/). 